\title{
Effect of water quality on algal diversity in various sites of district Charsadda, Khyber Pakhtunkhwa (KPK)-Pakistan
}

\author{
Zahir Shah ${ }^{1}$, Syed Zahir Shah ${ }^{1}$, Muhammad Shuaib ${ }^{2 *}$, Khan Niaz \\ $\mathrm{Khan}^{3}$, Tahir Khan ${ }^{4}$ and Fida Hussain ${ }^{3,5}$ \\ 1. Department of Botany, Islamia College Peshawar, KP-Pakistan \\ 2. School of Ecology and Environmental Science, Yunnan University, Kunming, Yunnan-China \\ 3. Department of Biology, Edwards College Peshawar, KP-Pakistan \\ 4. School of Life Sciences, Department of Botany, Yunnan University, Kunming-China \\ 5. Department of Botany, Qurtaba University Peshawar-Pakistan \\ *Corresponding author's email: zeyadz44@yahoo.com \\ Citation
}

Zahir Shah, Syed Zahir Shah, Muhammad Shuaib, Khan Niaz, Tahir Khan and Fida Hussain. Effect of water quality on algal diversity in various sites of district Charsadda, Khyber Pakhtunkhwa (KPK)-Pakistan. Pure and Applied Biology. Vol. 8, Issue 1, pp169-186. http://dx.doi.org/10.19045/bspab.2018.700175

\begin{tabular}{llll}
\hline \hline Received: 27/04/2018 & Revised: 29/06/2018 & Accepted: 16/10/2018 & Online First: 25/10/2018 \\
\hline
\end{tabular}

\section{Abstract}

Seasonal distribution of algae determined in three research sites of river Jindi, Pakistan. Samples of 5 classes having 46 families, 54 genera, 107 spp., out of 107 spp. $46.72 \%$ collected in winter, 53.27\% in summer seasons. The most abundant class Bacillariophyta with 24 genera, 46 spp. (46.9\%), followed by Chlorophyceae with 18genera, 33 spp. (30.8\%), Cyanophyceae with 8 genera, 20 spp. (18.69\%), Euglenophyceae with 3 genera, 6 spp. (5.60\%), Charophyceae with 1genus, 1 spp. (0.93\%) in both seasons. In winter season, abundant class Bacillariophyceae with 14 genera, 24 spp. (48.97\%), followed by Chlorophyceae with 11 genera, 22 spp. (44.89\%), Euglenophyceae 2 genera, 1 spp. Charophyceae with 1 genus, 1 spp. (2.04\%). In summer season, abundant class Bacillariophyceae with 10 genera, 22 spp. (38.59\%), followed by Cyanophceae 7 genera, 19 spp. (33.33\%), Chlorophyceae 7 genera, 11 spp. (19.29\%), Euglenophyceae 2 genera, $5 \mathrm{spp}$. (8.77\%). The genus spirogyra is abundant among all sites, shows wide range ecological amplitude, thus found in different habitats. The diatom, bluegreen algae dominated, summer season (38.59\%), and (33.33\%) respectively, followed by green algae $19.29 \%)$. The diatoms registered high numbers in summer $(48.97 \%)$, winter $(38.59 \%)$ respectively. The $\mathrm{pH}$ of water samples varied $7.35-8.89$, more or less alkaline in nature. High $\mathrm{pH}$ is positively correlated with algal growth. Turbidity ranged from 5-18 NTU. High turbidity decreases oxygenation, high penetration. TDS, TSS were positively correlated with number of species. TDS were 212.9-297.9 mg/L. The amount of TSS varied from 17-37 $\mathrm{mg} / \mathrm{L}, \mathrm{EC}$ value $365-812 \mu \mathrm{S} / \mathrm{cm}$. The optimum amount of EC favours growth, distribution of algae. Salinity value $0.5-2.1 \mathrm{mg} / \mathrm{L}$ suitable for the growth, distribution of algae. The total $\mathrm{CO}_{2}$ in water was 7.04-54.08 shows more respiration, results algal growth. The amount of DO varied from 2.5-3.8 mg/L. Nitrate as $\mathrm{N}_{2}$ content $0.05-1.8 \mathrm{mg} / \mathrm{L}$, Phosphate as TP range from $0.5-1.4$ $\mathrm{mg} / \mathrm{L}$ and $\mathrm{Ca}$ Hardness as $\mathrm{CaCO}_{3} 227-440 \mathrm{mg} / \mathrm{L}$.

Keywords: Algae; Dissolved $\mathrm{CO}_{2}$; DO; EC; TSS; TDS

\section{Introduction}

Algae are the simplest autotrophic plants without roots stem or leave and exist in variable sizes. Algae are abundant in every aquatic ecosystem in this biosphere [1]. As primary producers, they are inhabitants of 
moist, freshwater; brackish water and marine environments [2]. There are microscopic algal cells which cause water to look green, while some of the algae are macroscopic with longer and branchy structures which make them visible to the naked eye. In lake ecosystems, planktonic algae live in the open water and periphytic algae live in the littoral (benthic) areas usually attached to rock substrates. Algae possess chlorophyll-a as their primary photosynthetic pigment. Their sexual organs are not enclosed within sterile protective coverings [1, 3]. Algal flora is also considered a good indicator of water pollution [4]. Phytoplankton inhabiting the water body reflects the average ecological condition and may be used as an indicator of water quality [5]. Ohashi, [6] reported the harmful effect of nitrogen, DO, PO and $\mathrm{pH}$ increases due to the algal flora attached to the bottom of Shife River in Japan. Hall, [7] reported the effect of wastewater containing nitrogen on the aquatic community composition and variation with land settlement and concentration of nitrogen in sewage with urbanization.

The extensive use of pesticides on agricultural land and industrial effluents may lead to their presence in fresh waters environments [8]. Consequently increased water temperatures are associated with both eutrophication and Cyanobacteria blooms $[9,10]$. One main cause of the eutrophication, defined as organic matter production enhancement, is high dissolved nutrient concentration [11, 12]. The algal distribution and organic pollution in fifteen sites in rural and temple pond in Balrampur were studied for algae belonging to Chlorophyceae, Cyanophyceae, Euglenophyceae, and Bacillariophyceae [13]. When the water is alkaline and minerals are in abundance it increased the algal growth. Filamentous algae were found more prevailing during the spring season, while diatoms were four out of five in epilithic species. The variation in water quality is mainly responsible for the communities' determination [14].
Water quality is a term used to express the suitability of water to sustain various uses or processes. Any particular use will have certain requirements for the physical, chemical or biological characteristics of water, and can be measured by several factors such as the concentration of dissolved $\mathrm{O}_{2}$, and $\mathrm{CO}_{2}$, the amount of salt, or the amount of material suspended in water (turbidity). In some water bodies, the concentration of microscopic algae and quantities of pesticides, herbicides, heavy metals, and other contaminants may also be measured to determine water quality. Water quality is affected by a wide range of natural and human influences. The most important of the natural influences are geological, hydrological and climatic since these affect the quantity and the quality of water available $[12,15,16]$. A variety of physical and chemical variables will control the level of stratification. Thermal stratification then has a direct impact on the spatial and temporal distribution of the algae and the remainder of the biology of the lake $[17,18]$. Taxonomic groups with a small upper size range are also likely to be regulated strongly in lakes with intermediate and high nutrient levels, which support herbivorous zooplankton populations [18]. It is also known that many of the dinoflagellates such as Ceratium and Phormidium with their amour plate-like exterior are less prone to grazing than many other species [19]. The current paper aims to cover the algal diversity, water qualities, EC, Dissolved $\mathrm{CO}_{2}$, DO, TSS and TDS in local area district Charsadda, KPK, Pakistan.

\section{Materials and methods}

The present study comprises of the Identification, classification, and relative distribution of algal flora with respect to the effect of water quality from three different sites of the river Jindi, District Charsadda Khyber Pakhtunkhwa in two seasons (summer and winter). The study aims to explore algal diversity found in three different sites in two different seasons of the year with different physioco-chemical 
parameters of water of river Jindi, in which existent algal flora was inhibited. The study of algal flora was based on comparative bases. The comparative investigations of algal flora of different sites were mainly the nature and location of different sites as less polluted water, slightly polluted water and highly polluted water. Three main sites of river Jindi which were selected for the present study was Harichand Ziam Bridge, Sherpao Kanever Bridge, and Umerzai Cheena site (Figure 1).

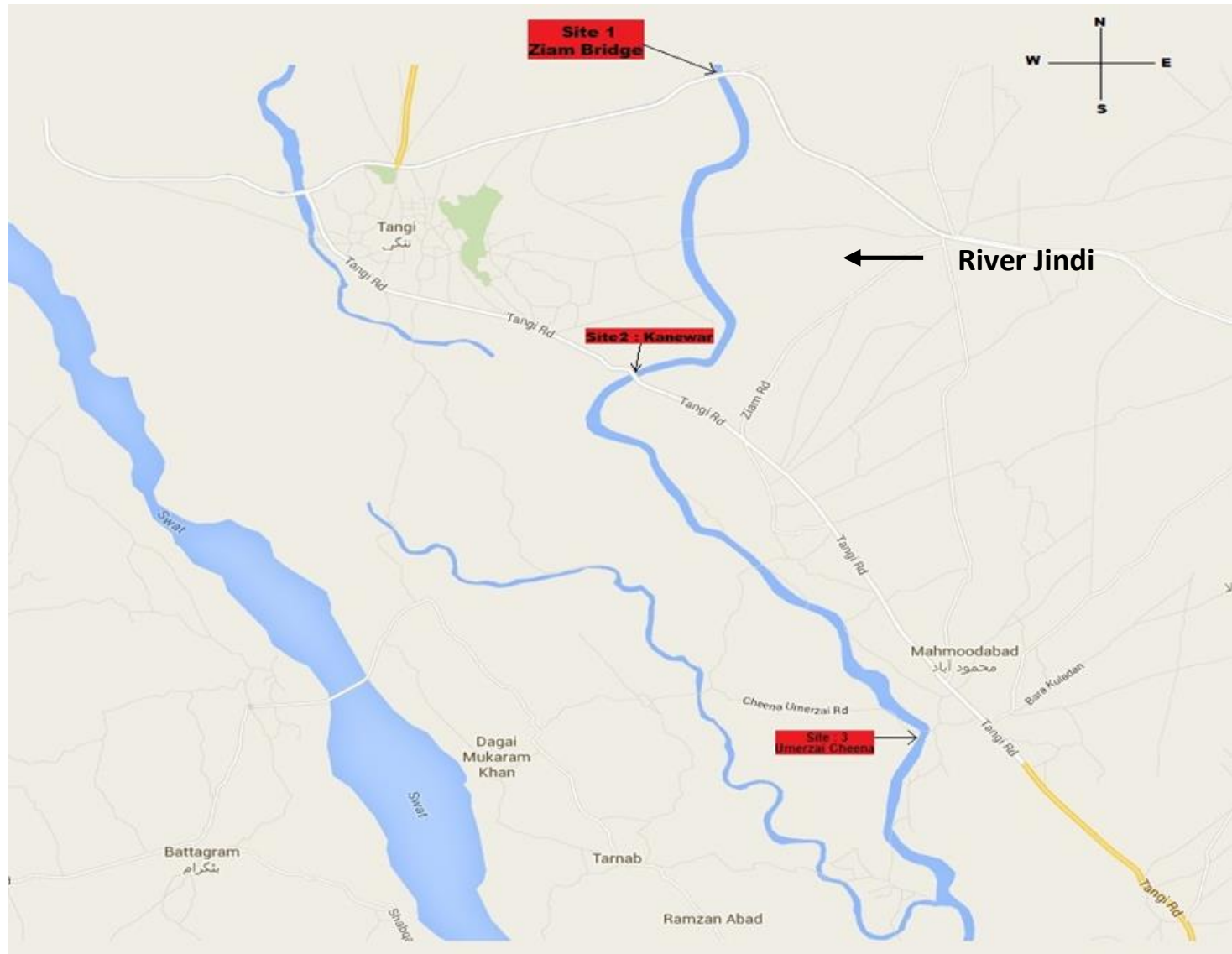

Figure 1. Map Showing collection site of river Jindi, District Charsadda, Pakistan

\section{Sampling of species}

Samples of algae and water were collected from the research sites/ locations. For this purpose, visits were made to collect the algae in summer and winter seasons. The collections were made by hand picking, squeezing and scraping the aquatic flora by the planktonic net, knife, glass slides, handpicking, squeezing and scratching of stones/ wood/plant material in selected sites of river Jindi. Seasonal distributions of algae within and among the site were determined by recording the presence of species in 10 samples from each site. The collected samples of algae and water from collection sites were brought to the laboratory of Botany Department Islamia College Peshawar in standard size bottles.

\section{Preservation of species}

The collected algal samples were transferred to collect plastic bottles and immediately preserved in $4 \%$ formalin solution. Temperature and $\mathrm{pH}$ of water samples were noted on spot of research areas with the help of digital portable $\mathrm{pH}$ cum temperature meter at the time of collection.

\section{Identification of the species}

Various groups of algae were identified using floristic literature. Identification was 
made with the help of Prescot, [20], Tiffany and Britton, [21], Faridi, [22], Shah, [23] and Shameel, [2]. Pictures were taken with the help of camera fixed on a microscope (Model Olympus $\mathrm{BH}_{2}$ ). Water samples were collected from research sites in clean bottles and were analyzed for physiocochemical Parameters at PCSIR Laboratories, Peshawar. Algal specimens were stored in the Herbarium of the Department of Botany, Islamia College Peshawar. Algae type, counts and species identification in addition to the physiochemical parameters $(\mathrm{pH}$, Temperature Turbidity, EC, Dissolve $\mathrm{CO}_{2}$, DO, TSS, TDS, Nitrogen content, TP, Total Hardness as $\mathrm{CaCO}_{3}$ ) were conducted according to the Standard Methods of Examination of Water and Waste Water

\section{Results}

A total of 107 species of different groups of algae were isolated both in winter and summer seasons from the research sites. Out of 107 species, 50 species were isolated in winter season which constitutes 46.72 percent of the total number while 57 species were isolated in the summer season; this constitutes 53.27 percent of the total species isolated. The most abundant class in both seasons was Bacillariophyceae with 24 genera and 46 species (46.9\%), Chlorophyceae with 18 genera and 33 species(30.8\%), class Cyanophyceae with 8 genera and 20 species(18.69\%),class Euglenophyceae with 3 genera and 6 species (5.60\%),class Charophyceae with one genus and one species $(0.93 \%)$ (Table 1).

In winter season the most abundant class was Bacillariophyceae with 14 genera and 24 species (48.97\%) followed by Chlorophyceae with 11 genera and 22 species (44.89\%), Euglenophyceae and Charophyceae with 1 species each (2.04\%).
In the summer season, the most abundant class was Bacillariophyceae with 10 genera and 22 species (38.59\%), followed by Cyanophyceae with 7 genera and 19 species (33.33\%), Chlorophyceae with 7 genera and 11 species (19.29\%) and Euglenophyceae with 2 genera and 5 species $(8.77 \%)$ (Table 1$)$.

The genera which were found in both seasons were Spirogyra, Euglena, Cymatopleura, Nitzschia, Diatoma, Synedra, Navicula, Hydrodictyon, Gomponema and Fragillaria. The most abundant genus among them was Spirogyra found at all sites is an apparent justification that this genus may have wide ecological amplitude and therefore occurs in different habitats.

The genera which were only found in summer season were Oscillatoria, Anabaena, Phormidium, Merismopodium, Aphanocapsa, Gloecapsa, Spirulina, Oedogonium, Ankistrodesmus, Haematococcus, Chlorococcum, Basicladia, Pinnularia, Achanthes, Phacus, and Euglena. The most abundant genus was Oscillatoria with 6 species followed by Anabaena with 4 species (Table 1).

\section{The result of the summer collection Cyanophyceae}

A total of 7 genera with 19 species of Cyanophyceae were identified from the collection sites samples from Jindi river of district Charsadda during the summer season of 2014. The most common genus was Oscillatoria with 7 species (36.84\%) of the total algal flora identified. the other genera were Anabaena with 4 species $(21.05 \%)$. The other genera were Phormedium, Merismopedia, and Gleocapsa with 2 species each (10.52\%) while Spirulina and Aphanocapsa with 1 species each (5.26\%) (Figure 2, Table 2). 
Table 1. Various genus occurrences at three selected sites with the different water quality of winter season

\begin{tabular}{|c|c|c|c|c|c|}
\hline \multirow{2}{*}{ S. No. } & \multirow{2}{*}{ Genus } & \multirow{2}{*}{ Species } & \multicolumn{3}{|c|}{ Occurrence / sites } \\
\hline & & & 1 & 2 & 3 \\
\hline \multirow{6}{*}{1} & \multirow{6}{*}{ Spirogyra } & S. pseuforidiana & $\ldots$ & + & + \\
\hline & & S. daedaleoides & + & + & + \\
\hline & & S. funtiformis & + & - & + \\
\hline & & S. tetrapla & + & + & - \\
\hline & & S. weberii & + & + & + \\
\hline & & S.pratensis & + & + & _- \\
\hline \multirow{4}{*}{2} & \multirow{4}{*}{ Closterium } & Closterium dianae & + & + & - \\
\hline & & C. leibleinii & + & + & + \\
\hline & & C. littorala & + & + & + \\
\hline & & C. moniliferum & + & + & + \\
\hline \multirow{2}{*}{3} & \multirow{2}{*}{ Cladophora } & Cladophora glomerata & + & _- & _- \\
\hline & & C.crispata & + & _ & - \\
\hline \multirow{2}{*}{4} & \multirow{2}{*}{ Ulothrix } & Ulothrix subconstricta & + & + & - \\
\hline & & U. tenuissima & + & + & _ \\
\hline 5 & Hyalotheca & Hyalotheca mucosa & + & + & + \\
\hline 6 & Hydrodictyon & H. reticulatum & + & + & - \\
\hline 7 & Schizomeris & S. leibleinii & + & + & - \\
\hline 8 & Chlorella & Chlorella vulgaris & + & - & + \\
\hline \multirow{2}{*}{9} & \multirow{2}{*}{ Tetraedron } & Tetraedron muticum & + & _- & + \\
\hline & & T. constiticum & + & + & + \\
\hline \multirow{2}{*}{10} & \multirow{2}{*}{ Chlamydomonas } & C. pyreneideum & + & + & - \\
\hline & & C. sphagnicola & + & _ & + \\
\hline \multirow{3}{*}{11} & \multirow{3}{*}{ Diatoma } & Diatoma anceps & + & + & - \\
\hline & & D. elongatum & - & + & - \\
\hline & & D. hiemale & + & + & - \\
\hline \multirow{4}{*}{12} & \multirow{4}{*}{ Synedra } & Synedra ulna & + & + & + \\
\hline & & S. ulna ver aequalis & - & + & - \\
\hline & & S. ulna ver danica & + & + & - \\
\hline & & S. rumpens & + & + & - \\
\hline \multirow{3}{*}{13} & \multirow{3}{*}{ Cymbella } & Cymbella turgid & + & - & + \\
\hline & & C. cistula & - & + & + \\
\hline & & C. tumida & + & + & - \\
\hline \multirow{3}{*}{14} & & G. eximinum & + & - & + \\
\hline & Gyrosigma & G. kuetzingii & - & + & + \\
\hline & & G. spencenii & + & + & - \\
\hline 15 & Cocconeis & C. placentula & + & + & - \\
\hline 16 & Stauroneis & S. anceps & + & + & - \\
\hline 17 & Melosira & M. granulata & - & + & - \\
\hline 18 & Gomphonema & G. alivaceum & - & + & - \\
\hline 19 & Nitzschia & N. linearis & + & + & - \\
\hline 20 & Cymatopleura & C. solea & & & \\
\hline 21 & Rhoicosphenia & R. currata & - & + & + \\
\hline 22 & Euglena & E. viridis & + & + & - \\
\hline 23 & Chara & C. vulgaris & + & - & - \\
\hline
\end{tabular}




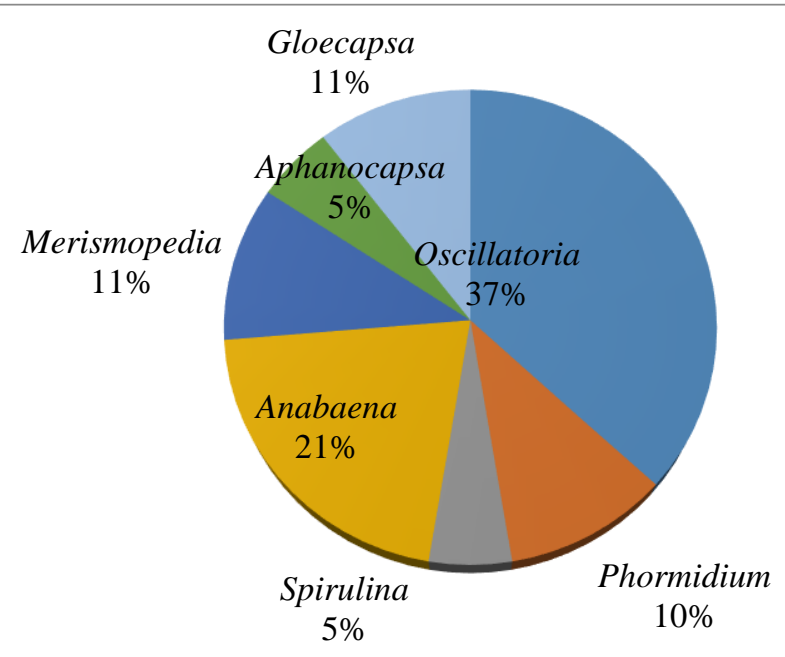

Figure 2. Genera wise percentage of Cyanophyceae in river Jindi, Charsadda District during summer season-2014

Table 2. A total number of algae, their \%age and total no. of species collected in summer from three different sites of river Jindi at Charsadda KP-Pakistan

\begin{tabular}{|c|c|c|c|c|c|c|}
\hline $\begin{array}{c}\text { S. } \\
\text { No. }\end{array}$ & Class & Order & Family & Genus & $\begin{array}{c}\text { No } \\
\text { of } \\
\text { Spp }\end{array}$ & Spp\%age \\
\hline \multirow{7}{*}{1} & \multirow{7}{*}{ Cyanophyceae } & Hormogonales & Oscillatoriaceae & Oscillatoria & 6 & 9.75 \\
\hline & & $1 /$ & $/ /$ & Phormidium & 2 & 4.87 \\
\hline & & $/ /$ & // & Spirulina & 1 & 2.43 \\
\hline & & Synechoccales & Merismopodiaceae & Aphanocapsa & 1 & 2.43 \\
\hline & & $/ /$ & $/ /$ & Merismopedia & 2 & 4.87 \\
\hline & & Hormogonales & Nostacaceae & Anabaena & 4 & 7.31 \\
\hline & & Chrococcales & Chrococcaceae & Gloecapsa & 2 & 2.43 \\
\hline \multirow{10}{*}{2} & \multirow{10}{*}{ Bacillariophyceae } & Surirealales & Surirellaceae & Cymatopleura & 3 & 4.87 \\
\hline & & Bacillariales & Bacillariaceae & Nitzschia & 3 & 7.31 \\
\hline & & Fragilariales & Fragilariaceae & Fragilaria & 2 & 4.87 \\
\hline & & $/ /$ & $/ /$ & Synedra & 2 & 4.87 \\
\hline & & Naviculales & Naviculaceae & Navicula & 2 & 4.87 \\
\hline & & Achanthales & Cocconeidaceae & Cocconeis & 1 & 2.43 \\
\hline & & Naviculales & Pinnulariaceae & Pinnularia & 3 & 7.31 \\
\hline & & Fragilariales & Fragilariaceae & Diatoma & 3 & 7.31 \\
\hline & & Cymbellales & Gomphonemataceae & Gomphonema & 2 & 4.87 \\
\hline & & Mastogloiales & Achanthaceae & Achanthes & 1 & 2.43 \\
\hline \multirow{7}{*}{3} & \multirow{7}{*}{ Chlorophyceae } & Chlorococcales & Hydrodictyaceae & Hydrodictyon & 1 & 2.43 \\
\hline & & Oedogoniales & Oedogoniaceae & Oedogonium & 1 & 2.43 \\
\hline & & $/ /$ & Oosystaceae & Ankistrodesmus & 1 & 2.43 \\
\hline & & Chlamydomonales & Haematococcaceae & Haematococcus & 1 & 2.43 \\
\hline & & Chlamydomonales & Chlorococcaceae & Chlorococcum & 1 & 2.43 \\
\hline & & Cladophorales & Cladophoraceae & Basicladia & 1 & 2.43 \\
\hline & & Conjugales & Zygnemaceae & Spirogyra & 5 & 4.87 \\
\hline \multirow{3}{*}{4} & \multirow{2}{*}{ Euglenophyceae } & Euglenales & Euglenaceae & Phacus & 2 & 4.87 \\
\hline & & $/ /$ & $/ /$ & Euglena & 3 & 2.43 \\
\hline & Grand Total & 18 & 21 & 26 & 57 & 99.78 \\
\hline
\end{tabular}




\section{Bacillariophyceae}

A total of 10 genera with 22 species of Bacillariophyceae were reported from the collected samples of river Jindi district Charsadda during the summer season of 2014. The most common genera were Cymatopleura, Nitzschia, Pinnularia and
Diatoma with 3 species each (13.63\%) followed by Fragilaria, Synedra, Navicula and Gomphonema with 2 species each $(9.09 \%)$. While the less frequent genera were Cocconeis and Achanthes with 1 species each (4.54\%) (Figure 3, Table 2, 3).

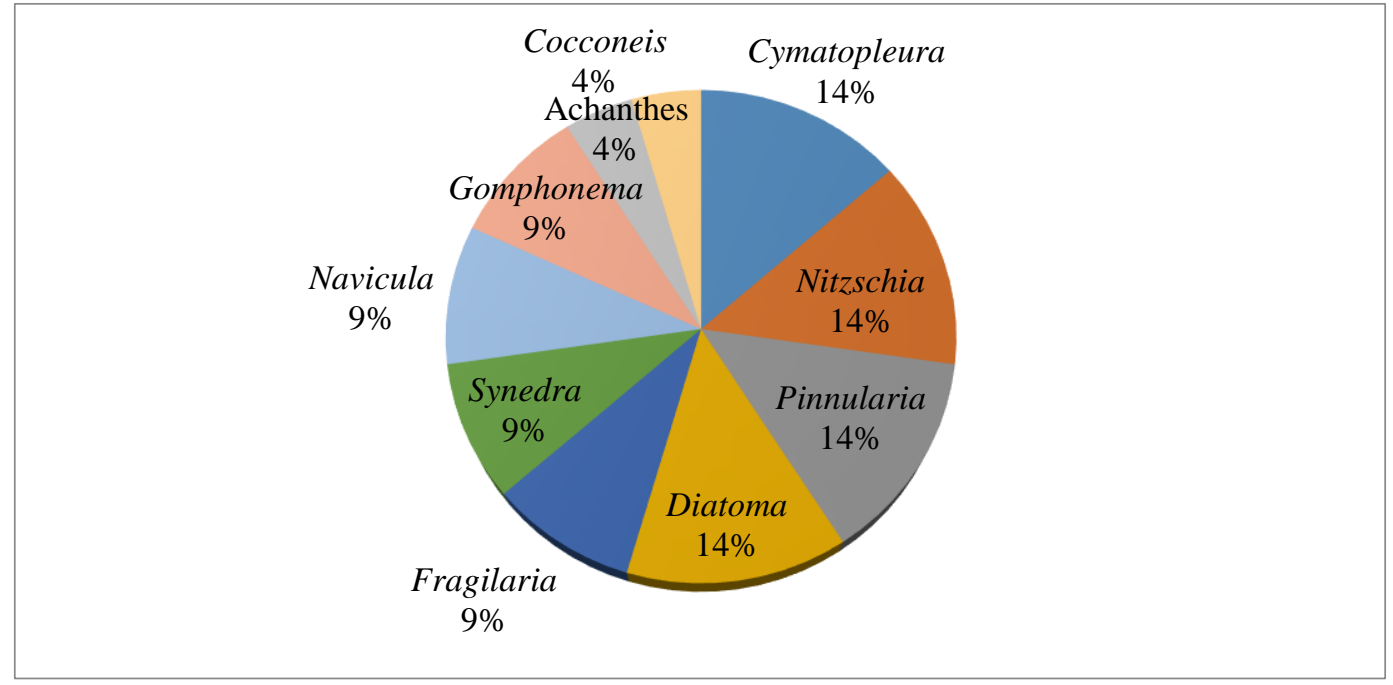

Figure 3. Genera wise percentage of Bacillariophyceae in river Jindi, Charsadda District during summer season-2014

Table 3. Various Genus occurrences at three selected sites with the different water quality of summer season

\begin{tabular}{|c|c|c|c|c|c|}
\hline \multirow{2}{*}{ S. No. } & \multirow{2}{*}{ Genus } & \multirow{2}{*}{ Species } & \multicolumn{3}{|c|}{ Occurrence / Site } \\
\hline & & & 1 & 2 & 3 \\
\hline \multirow{6}{*}{1} & \multirow{6}{*}{ Oscillatoria } & Oscillatoria chlorine & __ & + & + \\
\hline & & O.formosa & _ & + & + \\
\hline & & O. curviceps & _- & + & _ \\
\hline & & O. granulate & _- & + & + \\
\hline & & O.terebriformis & - & + & + \\
\hline & & O. chlorine & _- & + & - \\
\hline \multirow{3}{*}{2} & \multirow{3}{*}{ Diatoma } & Diatoma anceps & _ & $\ldots$ & - \\
\hline & & D. elongatum & _ & + & + \\
\hline & & D.hiemale & _- & + & _ \\
\hline \multirow{2}{*}{3} & \multirow{2}{*}{ Synedra } & Synedra ulna & + & + & + \\
\hline & & S. aequalis & & + & + \\
\hline \multirow{2}{*}{4} & \multirow{2}{*}{ Fragilaria } & Fragilaria cupusina & - & + & + \\
\hline & & $F$. virscens & - & + & - \\
\hline 5 & Ankistrodesmus & A. falcatus & - & + & - \\
\hline \multirow{3}{*}{6} & \multirow{3}{*}{ Gomphonema } & G. constriticum & _ & + & + \\
\hline & & G. capitatum & - & _- & + \\
\hline & & G. oleacea & + & + & + \\
\hline \multirow{2}{*}{7} & \multirow{2}{*}{ Navicula } & N. scoliopleuuroids & + & + & _ \\
\hline & & N. crucicula & _- & + & + \\
\hline 8 & Basicladiaoccurrences & B. chelonum & - & + & + \\
\hline \multirow{2}{*}{9} & \multirow{2}{*}{ Merismopedia } & M. convoluta & + & _ & + \\
\hline & & M. glauca & & & + \\
\hline
\end{tabular}




\begin{tabular}{|c|c|c|c|c|c|}
\hline 10 & Cocconeis & Cocconeis placentula & + & + & + \\
\hline 11 & Chlorococcum & C. humicola & - & + & _- \\
\hline 12 & Hormidium & H. klebesii & - & + & + \\
\hline 13 & Nitzschia & Nitzschia vermicularis & _ & _ & + \\
\hline & & N. acicularis & + & + & _ \\
\hline & & N.obtusa & _ & + & + \\
\hline 14 & Haematococcus & H. lacustris & - & - & + \\
\hline \multirow{5}{*}{15} & \multirow{5}{*}{ Spirogyra } & S. pseuforidiana & + & + & _- \\
\hline & & S. daedaleoides & + & + & + \\
\hline & & S. funtiformis & _ & + & + \\
\hline & & S. tetrapla & + & _ & _- \\
\hline & & S. weberi & _ & + & + \\
\hline 16 & Achanthes & Achanthes minutissima & $\ldots$ & + & _ \\
\hline 17 & Aphanocapsa & A. richteriana & _- & + & _ \\
\hline 18 & Spirulina & Spirulina major & _ & + & + \\
\hline 19 & Hydrodictyon & H. reticulatum & + & + & _ \\
\hline \multirow[t]{2}{*}{20} & Gloecapsa & G. crepidium & $\ldots$ & + & + \\
\hline & & G. pleurocapsoides & _ & + & + \\
\hline \multirow{2}{*}{21} & \multirow{2}{*}{ Anabaena } & A. variabilis & _ & _ & + \\
\hline & & A. unispora & $\ldots$ & + & + \\
\hline 22 & Euglena & Euglena viridis & + & _ & + \\
\hline \multirow{2}{*}{23} & \multirow{2}{*}{ Phormidium } & P. fragile & _ & _ & + \\
\hline & & P. foveolarum & $\ldots$ & + & + \\
\hline \multirow{3}{*}{34} & \multirow{3}{*}{ Cymatopleura } & C. ellipticavern spiralis & _- & + & + \\
\hline & & C. solea & $\ldots$ & + & _- \\
\hline & & C. spiralis & _ & + & + \\
\hline \multirow{2}{*}{35} & \multirow{2}{*}{ Phacus } & P. acuminatus & $\ldots$ & + & + \\
\hline & & Phacus & - & + & + \\
\hline \multirow{2}{*}{36} & \multirow{2}{*}{ Navicula } & N. mutica & + & + & _ \\
\hline & & N. scoliopleuroides & + & + & - \\
\hline \multirow{3}{*}{37} & \multirow{3}{*}{ Pinnularia } & P. gibba & _ & + & + \\
\hline & & P. divergens & $\ldots$ & $\ldots$ & + \\
\hline & & P. appendiculata & _- & + & + \\
\hline 38 & Oedogonium & O. prinshemii & + & + & + \\
\hline
\end{tabular}

\section{Chlorophyceae}

A total of 7 genera with 11 species of Chlorophyceae were identified from the collection sites from collected samples of river Jindi district Charsadda during the summer season of 2014. The most common genus was Spirogyra of family Zygnemaceae with 5 species $(45.45 \%)$ followed by Hydrodictyaceae, Oedogoniaceae, Oosystaceae, Haematococcaceae with 1 species each $(9.09 \%)$. While other genera were Chlorococcaceae and Cladophoraceae, also with 1 species each (9.09\%) (Figure 4, Table 2 \& 3).

\section{Euglenophyceae}

Sum of 2 genera with 5 species of Euglenophyceae was identified from the collection sites from collected samples of river Jindi district Charsadda during the summer season of 2014. The 2 genera were phacus with 2 species (40\%) followed by Euglena with 3 species (60\%) (Figure 5).

Chlorophyceae

Sum of 11 genera with 22 species of Chlorophyceae was identified from the collection sites from collected samples of river Jindi district Charsadda during the winter season of 2014. The most abundant genera were spirogyra $(22.72 \%)$ and Closterium (18.1\%) with 5 and species respectively while Cladophora (9.09\%), 
Ulothrix (9.09\%), Chlamydomonas (9.09\%)and Cosmarium $(9.09 \%)$ with 2 species each while Hyalotheca, Chlorella,
Schizomeris, Tetraedron and Hydrodictyon with 1 species each having same percentage $(4.54 \%)$ (Figure 6, 7).

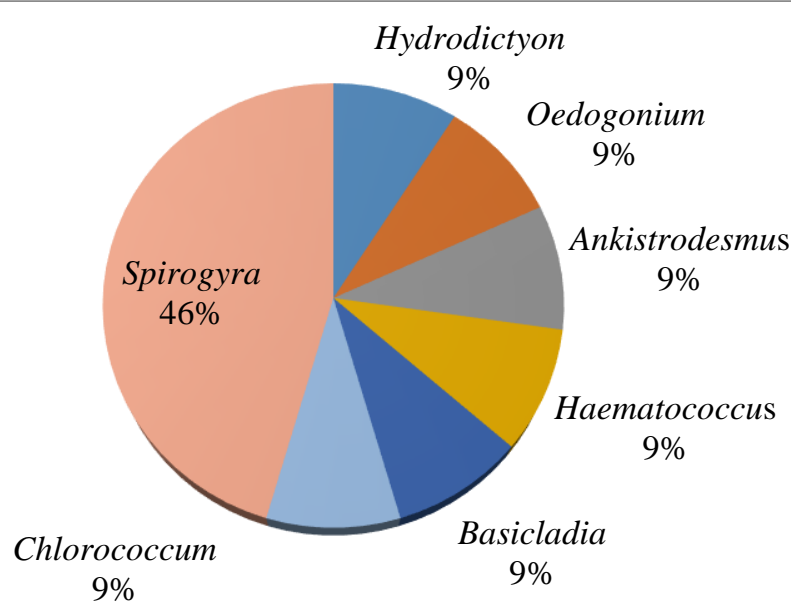

Figure 4. Genera wise percentage of Chlorophyceae in River Jindi, Charsadda District during summer season-2014

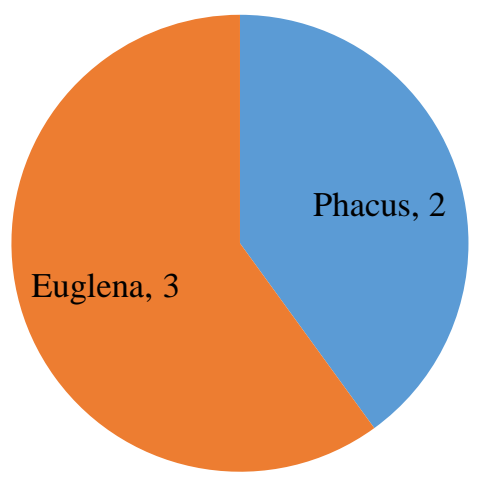

Figure 5. Genera wise percentage of Euglenophyceae in river Jindi, Charsadda District during summer season-2014

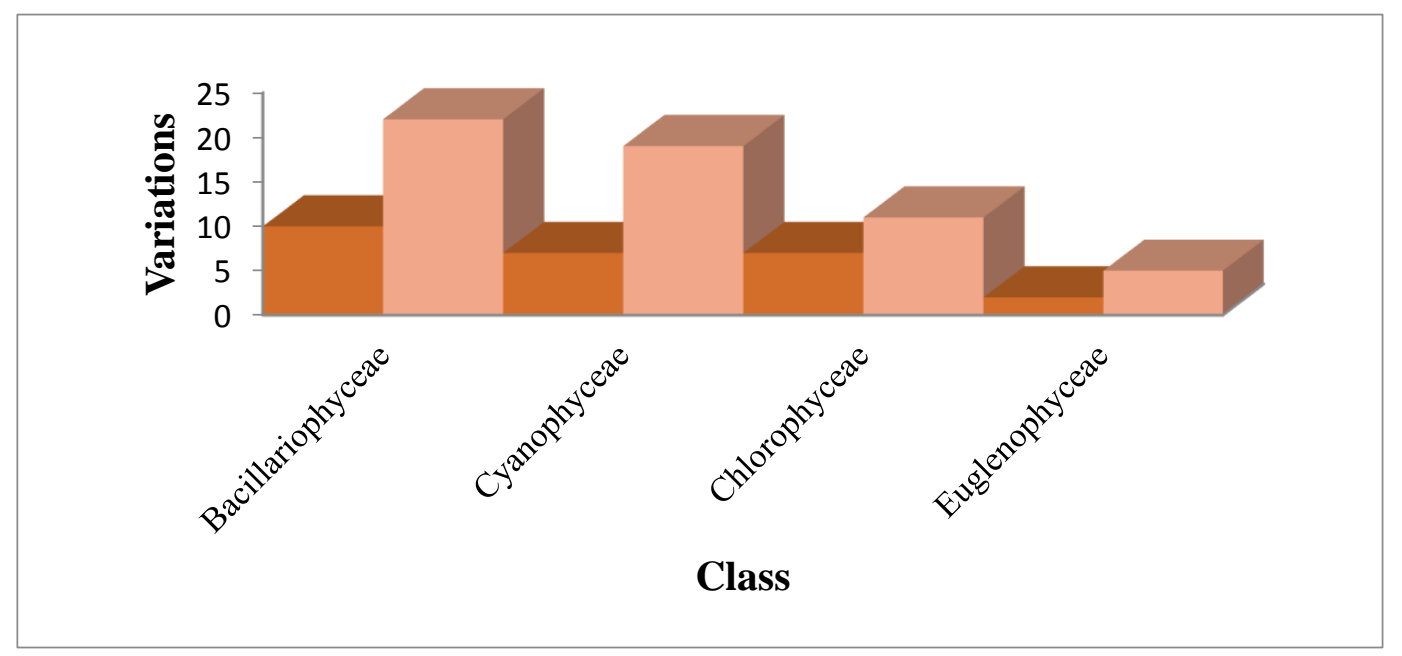

Figure 6. Seasonal variation of algae in summer season results of the winter collection 


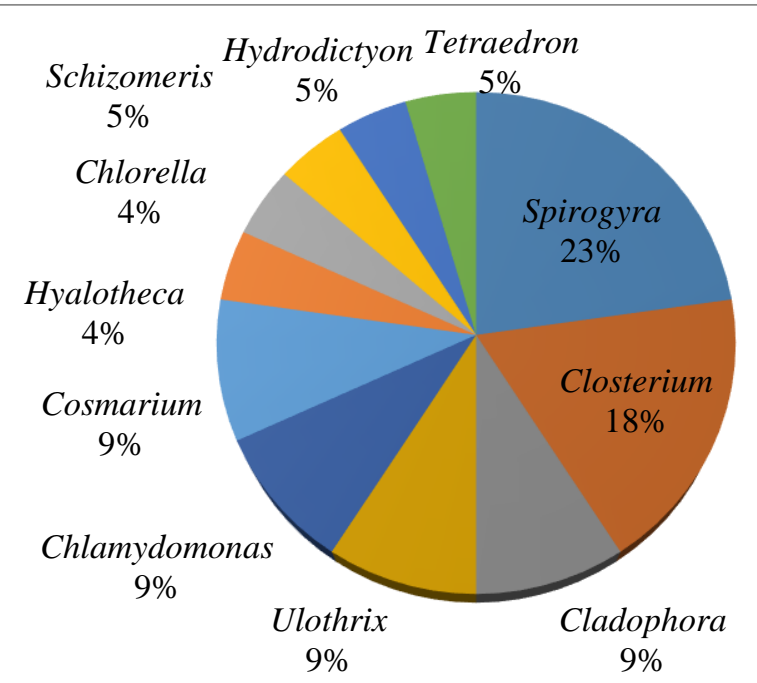

Figure 7. Genera wise percentage of Chlorophyceae in river Jindi, Charsadda District during winter season-2014

\section{Bacillariophyceae}

Sum of 14 genera with 24 species of Bacillariophyceae was identified from the collection sites from collected samples of river Jindi district Charsadda during the winter season of 2014. The most abundant genera were Synedra $(16.6 \%)$ with 4 species followed by Diatoma (12.5\%),
Gyrosigma (12.5\%), pinnularia (12.5\%) and Cymbella (12.5\%) with 3 species each while other were Fragilaria, Gomphonema, Rhoicosphenia with 2 species each and Navicula, Stauroneis, Cymatopleura, Cocconeis, Melosira, Cyclotella, and Nitzschia $(4.16 \%)$ with 1 species each (Figure 8).

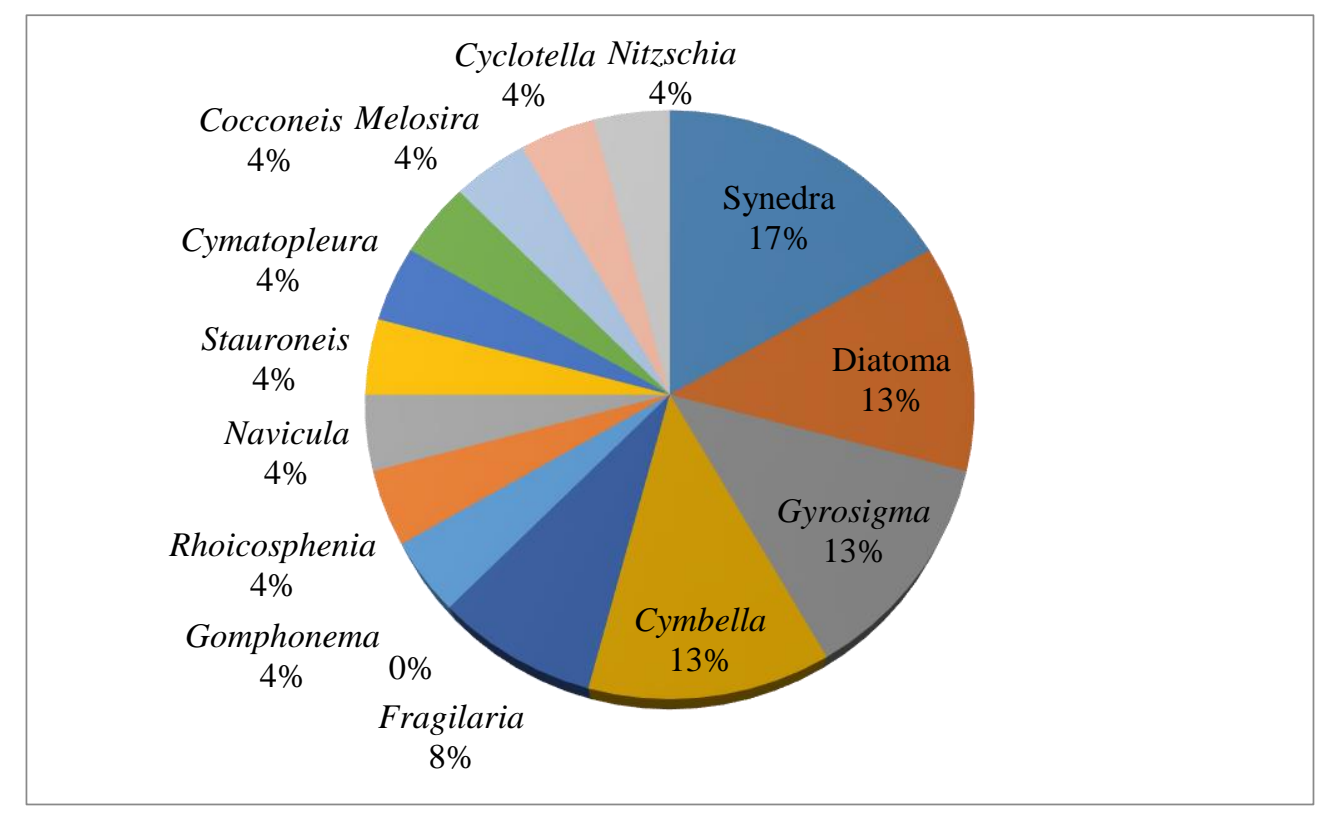

Figure 8. Genera wise percentage of Bacillariophyceae in river Jindi, Charsadda district during winter season-2014 


\section{Charophyceae}

Genus Chara, family Characeae with only 1 species $(100 \%)$ was collected from river Jindi during winter 2014 (Figure 9).

\section{Cyanophyceae}

Genus Rhabdoderma family
Synechococcaceae with only 1 species (100\%) was collected (Figure 9).

\section{Euglenophyceae}

Genus Euglena, family Euglenaceae with only 1 species (100\%) was collected during winter 2014 from river Jindi (Figure 9).

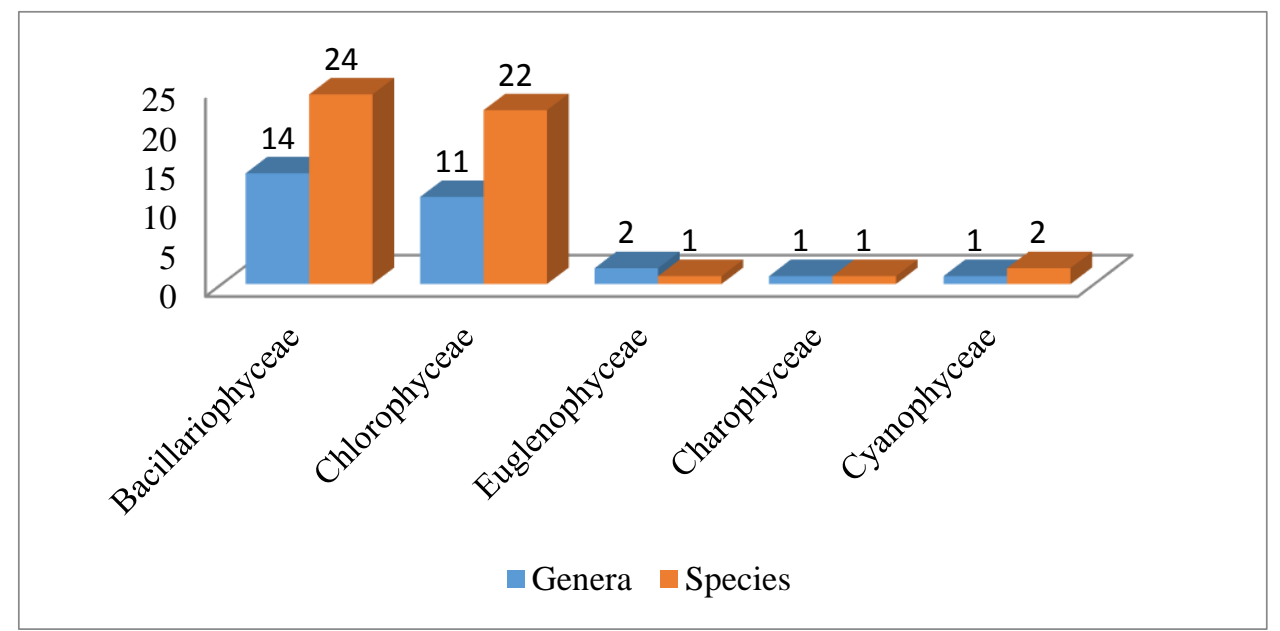

Figure 9. Seasonal variation of algae in the winter season

Chemical Analysis of the three types of water

\section{Measurements and results}

The range of $\mathrm{pH}$ is 7.35-8.84 (favorable for the growth of Chlorophyceae and Bacillariophyceae), The range of temperature 24-27 (favorable for algal growth), Turbidity 13-23 (high turbidity decreases light penetration and oxygenation), TSS (total suspended salts) 17-60) high TSS favoures algal growth, TDS (total dissolved solids) 254.2-327.4 number of algal species increases with increase in TDS. DO (dissolved oxygen) more oxygen in water favorable algal growth, Free $\mathrm{CO}_{2}$ : luxurious algal growth favors more co2 release, High total N/P accelerate algal growth (Figure $10(\mathrm{a}, \mathrm{b})$, Table 4).

Site information, species collected and chemical analysis of water of river Jindi during summer 2014

\section{Less polluted water}

The Less polluted water is mainly present in Harichand Ziam, the total recorded species of this various site are; Total 6 genera with 11 species of unicellular and filamentous green algae and 5 genera and 11 species of Bacillariophyceae and only 1 species of genus Euglena of Euglenophyceae were identified from the collected samples of Harichand Ziam bridge.

The prevalent genus was Spirogyra with 5 species followed by Hydrodictyon, Oedogoniaceae, Oosystaceae, and Haematococcaceae with 1 species each. While other genera were Chlorococcaceae, Cladophoraceae, and Zygnemaceae also with 1 species each. In Bacillariophyceae, the most abundant genera were Cymatopleura with 3 species followed by Synedra, Nitzschia, Cocconeis, and Gomponema with 2 species each. While genus Euglena with 1 species.

The chemical analysis at Less polluted water revealed that total hardness as $\mathrm{CaCO}_{3}$ is $227 \mathrm{mg} / \mathrm{L}$, phosphorus content is 1.4 $\mathrm{mg} / \mathrm{L}$ and Nitrogen content is $0.78 \mathrm{mg} / \mathrm{L}$, Free $\mathrm{CO}_{2}$ is $54.08 \mathrm{mg} / \mathrm{L}$, Dissolve Oxygen is $3.8 \mathrm{mg} / \mathrm{L}$ and TDS is $451.9 \mathrm{mg} / \mathrm{L}$, TSS is $17 \mathrm{mg} / \mathrm{L}$, Turbidity of water is 7 NTU, Salinity is $0.5 \mathrm{ppt}$, Electrical Conductivity is $812 \mu \mathrm{S} / \mathrm{cm}$, Temperature of water is 27 $0 \mathrm{C}, \mathrm{pH}$ of water is 8.84 (Table 4).

\section{Slightly polluted water}

Near Sherpao village at Kanever bridge over Jindi river the water is slightly 
polluted, the total recorded Species from this site are; Total genera 10 with 22 species of Bacillariophyceae were identified from the collected samples near Kanever bridge Sherpao.

The most common genera were Cymatopleura, Nitzschia, Pinnularia, and Diatoma with 3 species each followed by Fragilaria, Synedra, Naviculaand Gomphonema with 2 species each. While the less frequent genera were Cocconeis and Achanthes with1 specie each. The Chlorophyceae were represented by 8 genera and 8 species that is Ankistrodesmus, Basicladia, Hormidum, Achanthes, Aphanocapsa, Hydrodictyon and Oedogonium each with one species each.

The chemical analysis at slightly polluted water revealed that total hardness as $\mathrm{CaCO}_{3}$ is $277 \mathrm{mg} / \mathrm{L}$, phosphorus content is 0.8 $\mathrm{mg} / \mathrm{L}$ and Nitrogen content is $0.56 \mathrm{mg} / \mathrm{L}$, Free $\mathrm{CO}_{2}$ is $35.06 \mathrm{mg} / \mathrm{L}$, Dissolve Oxygen is $2.7 \mathrm{mg} / \mathrm{L}$ and TDS is $381.1 \mathrm{mg} / \mathrm{L}$, TSS is $20 \mathrm{mg} / \mathrm{L}$, Turbidity of water is $10 \mathrm{NTU}$, Salinity is $0.3 \mathrm{ppt}$, Electrical Conductivity is $730 \mu \mathrm{S} / \mathrm{cm}$, Temperature of water is 24 $0 \mathrm{C}, \mathrm{pH}$ of water is 8.41 (Table 4).

\section{Highly polluted water}

Water is highly polluted as the river passes through the villages of district Charsadda like Sherpao, Umerzai, Turangzai samples were collected from Umerzai Cheena Bridge over Jindi river.

The total recorded algae which were identified from the collection sites were 9 genera with 24 species belonging to Cyanophyceae and Euglenophyceae.

The most common and prevalent genus was Oscillatoria with 7 species of the total algal flora identified. The other genera were Anabaena with 4 species. The other genera were Phormedium, Merismopedia, and Gloecapsa with 2 species each while Spirulina and Aphanocapsa with 1 species each. Euglenophyceae was recorded with 2 genera and 5 species, Phacus with 2 species followed by Euglena with 3 species.

The chemical analysis at slightly polluted water revealed that total hardness as $\mathrm{CaCO}_{3}$ is $337 \mathrm{mg} / \mathrm{L}$, phosphorus content is 1.2 $\mathrm{mg} / \mathrm{L}$ and Nitrogen content is $1.8 \mathrm{mg} / \mathrm{L}$, Free $\mathrm{CO}_{2}$ is $50.03 \mathrm{mg} / \mathrm{L}$, Dissolve Oxygen is $2.5 \mathrm{mg} / \mathrm{L}$ and TDS is $437.9 \mathrm{mg} / \mathrm{L}$, TSS is $25 \mathrm{mg} / \mathrm{L}$, Turbidity of water is $18 \mathrm{NTU}$, Salinity is $0.2 \mathrm{ppt}$, Conductivity is 606 $\mu \mathrm{S} / \mathrm{cm}$, Temperature of water is $25.50 \mathrm{C}, \mathrm{pH}$ of water is 7.35 .

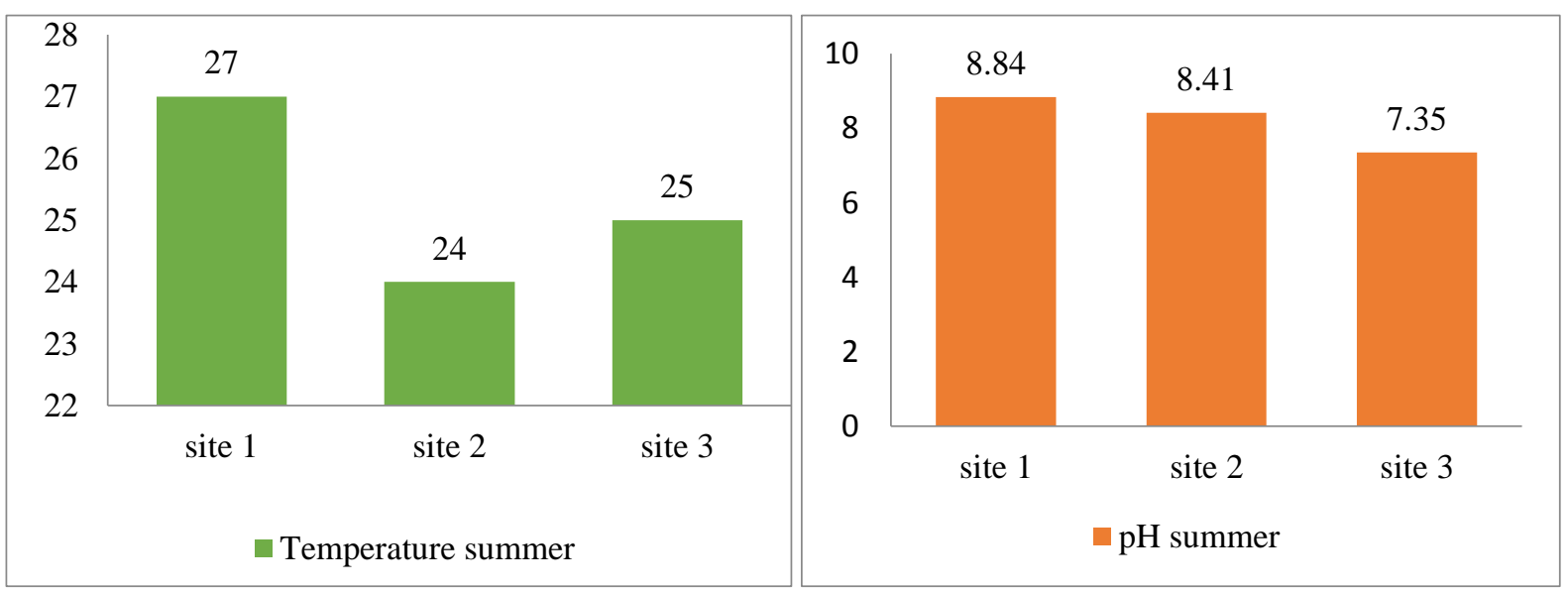

Figure 10. (A) Seasonal variation of $\mathrm{pH}$ value of summer season (B) Seasonal variation of Temperature of the summer season

\section{Chemical Analysis of the three types of water}

Measurements and results

The range of $\mathrm{pH}$ is 7.35-8.84(favorable for the growth of Chlorophyceae and
Bacillariophyceae), The range of temperature 24-27(favourable for algal growth), Turbidity 13_23(high turbidity decreases high penetration and oxygenation), TSS(total suspended 
salts)17-60)high TSS favoures algal growth, TDS(total dissolved solids)254.2327.4 number of algal species increases with increase in TDS, DO(dissolved oxygen)more oxygen in water favorable algal growth, Free $\mathrm{CO}_{2}$ :luxurious algal growth favors more $\mathrm{CO}_{2}$ release, High total $\mathrm{N} / \mathrm{P}$ accelerate algal growth.

Site information, species collected and chemical analysis of water of river Jindi during winter 2014

Less polluted water

The Less polluted water is mainly present in Harich and Ziam bridge up to Kanever Sherpao Tehsil Tangi, the total recorded species of these various sites are; Total 11 genera with 22 species of unicellular and filamentous algae belonging to Chlorophyceae were identified from the collected samples of Harichand Ziam. The most abundant genera were Spirogyra and Closterium with 5 and 4 species respectively while Cladophora, Ulothrix, Chlamydomonas, and Cosmarium with 2 species each while Hyalotheca, Chlorella, Schizomeris, Tetraedron and Hydrodictyon with 1 species each having the same percentage. The chemical analysis at slightly polluted water revealed that total hardness as $\mathrm{CaCO}_{3}$ is $227 \mathrm{mg} / \mathrm{L}$, phosphorus content is $1.4 \mathrm{mg} / \mathrm{L}$ and Nitrogen content is $0.07 \mathrm{mg} / \mathrm{L}$, Free $\mathrm{CO}_{2}$ is $7.04 \mathrm{mg} / \mathrm{L}$, Dissolve Oxygen is $2.5 \mathrm{mg} / \mathrm{L}$ and TDS is $297.9 \mathrm{mg} / \mathrm{L}$, TSS is $23 \mathrm{mg} / \mathrm{L}$, Turbidity of water is 5 NTU, Salinity is 0.3 ppt, Electrical Conductivity is $812 \mu \mathrm{S} / \mathrm{cm}$, Temperature of water is $150 \mathrm{C}, \mathrm{pH}$ of water is 8.89 .

\section{Slightly polluted water}

Near Sherpao village at Kanever bridge over Jindi river the water is slightly polluted, the total recorded species from this site are; Total genera 15 with 24 species of Bacillariophyceae and genus Chara with one species were identified from the collected samples near Kanever bridge Sherpao.The most abundant genera were Synedra with 4 species followed by Diatoma, Gyrosigma, Pinnularia and Cymbella with 3 species each while other were Fragilaria, Gomphonema, Rhoicosphenia with 2 species each Navicula, Stauroneis, Cymatopleura, Cocconeis, Melosira, Cyclotella, and Nitzschia with 1 species each and genus Chara with one species. The chemical analysis at slightly polluted water revealed that total hardness as $\mathrm{CaCO}_{3}$ is $423 \mathrm{mg} / \mathrm{L}$, phosphorus content is $1.2 \mathrm{mg} / \mathrm{L}$ and Nitrogen content is $1.5 \mathrm{mg} / \mathrm{L}$, Free $\mathrm{CO}_{2}$ is $7.04 \mathrm{mg} / \mathrm{L}$, Dissolve Oxygen is $2.9 \mathrm{mg} / \mathrm{L}$ and TDS is $281.1 \mathrm{mg} / \mathrm{L}$,TSS is $29 \mathrm{mg} / \mathrm{L}$, Turbidity of water is 7 NTU, Salinity is 0.3 ppt, Electrical Conductivity is $730 \mu \mathrm{S} / \mathrm{cm}$, Temperature of water is $120 \mathrm{C}, \mathrm{pH}$ of water is 8.45 (Table 5).

Table 5. Chemical Analyses of three types of water of winter season Method Used: Standard Methods for the Examination of water and wastewater 20th Edition, 2005

\begin{tabular}{|c|c|c|c|c|c|c|c|}
\hline Parameters & Method & Units & $\begin{array}{c}\mathbf{1} \\
\text { Site }\end{array}$ & $\begin{array}{c}\mathbf{2} \\
\text { Site }\end{array}$ & $\begin{array}{c}\mathbf{3} \\
\text { Site }\end{array}$ & $\begin{array}{c}\text { Mean } \\
\text { SD } \pm\end{array}$ & Water Q standards \\
\hline $\mathrm{pH}$ & $4500-(\mathrm{H}+\mathrm{B})$ & $\mathrm{mol} / \mathrm{L}$ & 8.89 & 8.45 & 7.95 & $\begin{array}{c}8.43 \\
0.470319\end{array}$ & $6.5-8.5$ \\
\hline Temperature & & $(0 \mathrm{C})$ & 15 & 12 & 13 & $\begin{array}{c}13.3 \\
1.527525\end{array}$ & $16-40$ \\
\hline Conductivity & $2510-(\mathrm{B})$ & $\mu \mathrm{S} / \mathrm{cm}$ & 517 & 445 & 365 & $\begin{array}{c}442.3 \\
76.03508\end{array}$ & $1000 \mu \mathrm{S} / \mathrm{cm}$ \\
\hline Salinity & & $\mathrm{Ppt}$ & 0.4 & 0.2 & 0.2 & $\begin{array}{c}0.3 \\
0.11547\end{array}$ & $<0.5-1$ \\
\hline Turbidity & $\begin{array}{c}\text { Nephelometric } \\
\text { Method }\end{array}$ & $\mathrm{NTU}$ & 5 & 7 & 12 & $\begin{array}{c}8 \\
3.605551\end{array}$ & NTU(Standardized) \\
\hline TSS & $2540-(\mathrm{D})$ & $\mathrm{mg} / \mathrm{L}$ & 23 & 29 & 37 & $\begin{array}{c}29.6 \\
7.023769\end{array}$ & $<80$ \\
\hline TDS & $2540-(\mathrm{C})$ & $\mathrm{mg} / \mathrm{L}$ & 297.9 & 281.1 & 212.9 & 263.9 & $<400$ \\
\hline
\end{tabular}




\begin{tabular}{|c|c|c|c|c|c|c|c|}
\hline & & & & & & 45.0157 & \\
\hline $\begin{array}{c}\text { DO(Dissolved } \\
\text { Oxygen) }\end{array}$ & $4500-\mathrm{OG}$ & $\mathrm{mg} / \mathrm{L}$ & 2.5 & 2.9 & 2.8 & $\begin{array}{c}2.73 \\
0.208167\end{array}$ & $>5$ \\
\hline Free $\mathrm{CO}_{2}$ & $4500-\mathrm{CO} 2 \mathrm{G}$ & $\mathrm{mg} / \mathrm{L}$ & 14.02 & 7.04 & 10.56 & $\begin{array}{c}10.54 \\
3.490043\end{array}$ & $<20-<60$ \\
\hline $\begin{array}{c}\text { Nitrogen } \\
\text { Content }\end{array}$ & $4500-\mathrm{N}$ & $\mathrm{mg} / \mathrm{L}$ & 0.05 & 0.07 & 1.1 & $\begin{array}{c}0.04 \\
0.600528\end{array}$ & $<103$ as N gas \\
\hline $\begin{array}{c}\text { Phosphorus } \\
\text { Content/TP }\end{array}$ & $4500-\mathrm{PD}$ & $\mathrm{mg} / \mathrm{L}$ & 0.5 & 0.4 & 0.7 & $\begin{array}{c}0.53 \\
0.152753\end{array}$ & \\
\hline $\begin{array}{c}\text { Total } \\
\text { Hardness as } \\
\text { CaCO }\end{array}$ & $2540-(\mathrm{D})$ & $\mathrm{mg} / \mathrm{L}$ & 440 & 423 & 327 & $\begin{array}{c}396.66 \\
60.92892\end{array}$ & 500 \\
\hline
\end{tabular}

\section{Highly polluted water}

Water is highly polluted as the river passes through the main villages of District Charsadda like Sherpao, Umerzai, Turangzai Utmanzai and Rajjar because of the addition of household and agricultural polluted water which badly affect the Chemistry of water. The total recorded algae which ware identified from the collection sites were 10 genera with 14 species belonging Bacillariophyceae, Cyanophyceae, and Euglenophyceae. The most abundant genera were Synedra with 4 species followed by Diatoma Gyrosigma, Pinnularia and Cymbella with 3 species each while other were Fragilaria, Gomphonema, Rhoicosphenia with 2 species each.

\section{Both Genus Rhabdoderma and Genus Euglena have only 1 species each}

The chemical analysis at slightly polluted water revealed that total hardness as $\mathrm{CaCO}_{3}$ is $337 \mathrm{mg} / \mathrm{L}$, phosphorus content is 1.7 $\mathrm{mg} / \mathrm{L}$ and Nitrogen content is $1.1 \mathrm{mg} / \mathrm{L}$, Free $\mathrm{CO}_{2}$ is $10.56 \mathrm{mg} / \mathrm{L}$, Dissolve Oxygen is $2.8 \mathrm{mg} / \mathrm{L}$ and TDS is $212.9 \mathrm{mg} / \mathrm{L}$, TSS is $37 \mathrm{mg} / \mathrm{L}$, Turbidity of water is $12 \mathrm{NTU}$, Salinity is $0.02 \mathrm{ppt}$, Electrical Conductivity is $606 \mu \mathrm{S} / \mathrm{cm}$, Temperature of water is 13 $0 \mathrm{C}, \mathrm{pH}$ of water is 7.35 .

\section{Discussion}

In the set of samples from research sites 5 classes having 46 families, 54 genera and 107 species were recorded belonging to Chlorophyta, Bacillariophyta, Cyanophyta while the least were Euglenophyta and Charophyta with fewer species in two seasons, winter and summer. The diatoms and the blue-green algae dominated the summer season $(38.59 \%)$ and $(33.33 \%)$ respectively, followed by green algae (19.29\%). The diatoms registered the highest number in seasons, summer and winter, (48.97\%) and (38.59\%) respectively. The diversity and abundance of the diatoms and blue-green algae showed a polluted environment, which is similar to the study conducted by Venkateswarlu, [24], Vijayakumar et al. [25] they suggested that Cyanophyceae (blue-green algae) grow luxuriantly with great variety and abundance in water with less DO and oxidizable organic matter. The wastewater from municipality water and agricultural wastes showed a considerable amount of nitrates and phosphates, with an increased level of BOD and COD along with very low DO and turbidity. This could be the reason for the flourishing growth of Cyanophyceae.

Genus Chara was only found at site two (Sherpao Kanever bridge) at high $\mathrm{pH}$, high $\mathrm{CaCO}_{3}$ level and high water conductivity because of effluents discharge from nearby marble factory directly added to a water body where the luxurious growth of Chara can be seen as a justification of favorable growth condition for Chara. The genus Chara represented only by one species $C$. vulgaris, it was only confined to winter season [26, 27].

Bacillariophyta was the most dominant class having 46 species which is similar to the reports of Salim and Khan, [28] who reported 102 species of river water diatoms from whole Peshawar Valley. The 
difference between our results in the number of species was that because our algal study was confined only to winter and summer seasons of only District Charsadda of Peshawar valley.

Chlorophyta and Cyanophyta were the second dominant classes in our findings as they together included 52 species, 33 species of Chlorophyta and 19 species of Cyanophyta our results are similar to the observation of Sarim et al. [29] they also reported 39 species of Chlorophyceae from Peshawar Valley. The variation in collection points and the difference in localities could be one of the apparent reason for justification. Nawaz and Sarim, [30], who studied 33 species of Chlorophyta from Peshawar valley including district Charsadda. The result was further supported by Zaman and Sarim, [31] who also listed 47 species of Chlorophyta from Peshawar Valley. Anjum and Hussain, [32] reported 30 species of Cyanophyta (blue Green algae) including by our present study and this agreed with our result. Cyanophyta was the most prominent and abundant class in highly polluted points. Oscillatoria was the most abundant and represented genus in the present study investigation represented by 6 species, followed by Anabaena with 4 species, Merismopedia, Phormidium and Gloecapsa with 2 species each. The same study was conducted by Anjum and Hussain, [33] regarding the phylum Cyanophyta as the genera and species are the same. Nishat et al. [34] reported 4 species of Euglena and Phacus with 4 species each from Swat and Peshawar valley respectively whereas our study included that of 4 species of Euglena and 2 species of Phacus. The results correlate with the findings of Sarim in this respect of the reason for less number of species. The abundance of Cyanophyceae suggests highly polluted water condition .moreover the high water $\mathrm{pH}$ and Temperature favors the luxurious growth of blue-green algae. A high count of Anabaena is due to high temperature and the $\mathrm{pH}$ reached 7.35 which cause the bad odor to water.

Hussain, [35] reported 36 species among 26 genera, Cyanophyceae was represented by 6 genera and 10 species represented by Gloecapsa, Oscillatoria and Phormidium with 2 species further strengthened our findings which suggest the presence of Cyanophyceae represented by 4 genera and 19 species represented by Oscillatoria with 7species, Anabaena with 4 species and Merismopedia, Gloecapsa, Phormidium with 2 species each, while Spirulina and Aphanocapsa with 1 species each. Chlorophyceae was represented by 5 genera and 7 species but in our findings, Chlorophyceae was represented by 18 genera and 33 species, Bacillariophyceae was represented by 14 genera and 18 species but in our findings, Bacillariophyceae was represented by 24 genera and 46 species. The difference is due to seasonal variations and localities, moreover, our study was confined to two seasons summer and winter.

These different species have been reported from various localities from Jindi river during two season summer and winter. The difference in a number of algal species was due to the difference in location of sites and prevailing local conditions of the water bodies [36].

The $\mathrm{pH}$ of water samples varied from 7.35 to 8.89 and was more or less alkaline. In the present study, the $\mathrm{pH}$ of Harichand Ziam bridge site -1 , Sherpao Kanever bridge site - 2 were abundant and had more species diversity as compared to other sites. Results similar to Nishat, [34] investigated that high and suitable required level of $\mathrm{pH}$ accelerates and favor the growth of desmids and other aquatic plants respectively while low $\mathrm{pH}$ was toxic for them. For chemical parameters, the alkalinity reaches their highest in summer than winter. For $\mathrm{pH}$ the highest value in summer, autumn and then winter $(8.84,7.35,7.7)$. High turbidity decreases high penetration of light and oxygenation, hence causes a decreased level of species growth and number in our 
study turbidity range from (5-18 NTU). A parameter such as Total Dissolved Solids and Total Suspended Solids positively correlated and affected the growth and number of species. The number of species increased with increasing total dissolved solids and total suspended solids in the water. In the present investigation, the total dissolved solids $(212.9-297.9 \mathrm{mg} / \mathrm{L})$ showing the concentration of Total Dissolved Solids of water which affects the distribution of algae. The number of TDS varied from $(212.9-437.9 \mathrm{mg} / \mathrm{L})$ and TSS varied from $(17-37 \mathrm{mg} / \mathrm{L})$ which suit the distribution of algae. It was observed that as with the increase in TSS and TDS, algal species promoted. The present findings are similar to those of Leghari et al. [37] who observed the similar relationship. The higher value of TSS indicates the high concentration of various nonliving particulates matters originate as catchments, derived salts, clayey mud, organic matter of plants and animals etc are present in the water. It increases the turbidity of water. EC $(365-812 \mu \mathrm{S} / \mathrm{cm})$ shows the presence of soluble salts in the water body. The optimum amount of EC favors growth and distribution of algal species.

The similar studies were conducted by Leghari et al. [38] who studied and compared

The electrical conductivity of both freshwater with marine water( brackish water) to find out their effect on growth relation of algal flora. The result was observed that in freshwater optimum conductivity level accelerates algal growth and had 45 species, in comparison to marine water which has 9 species with high conductivity. Low level of salts mainly $\mathrm{NaCl}$ in terms of Salinity $(0.5-2.1 \mathrm{mg} / \mathrm{L})$ was the most suitable level for the growth and distribution of algae, in our findings, the recorded salinity value was (0.2-0.4). Results are similar to those of Lealand et al. [39] reported that minute amount of $\mathrm{NaCl}$ promote the algal growth while high value causes growth retardation. The decreasing
$\mathrm{CO}_{2}$ (7.04 -54.08), nitrate as Nitrogen content $(0.05-1.8 \mathrm{mg} / \mathrm{L})$, phosphate as TP $(0.5-1.4 \mathrm{mg} / \mathrm{L})$ and calcium hardness $(227-$ $440 \mathrm{mg} / \mathrm{L}$ ) increased the number of algal species which correspond to Leghari et al. [38] concluded that high $\mathrm{CO}_{2}$ level, phosphates nitrates, and Total hardness as $\mathrm{CaCO}_{3}$ generally enhanced the algal species and does support the present findings.

The amount of DO (Dissolved Oxygen varied from $2.5-3.8 \mathrm{mg} / \mathrm{L}$ indicate more Oxygen in water hence favorable for algal growth. The present study correlates with reports of Sarim and Ali [31] who observed the high DO promote the algal growth. The Turbidity among the various points was recorded from 5-18 NTU. Most commonly, low level of Turbidity favors the growth and distribution of algae while high value was not suitable for the growth and distribution of algal flora by decreasing light penetration and oxygenation. Similarly, oxygen decreases with high temperature. The seasonal variation of algal species, counts and that mostly depends on the $\mathrm{pH}$ value, clarity of water, sunlight transmission, amount of nutrients and the nature of water, Also the algae distribution patterns were increased because the type of physical and chemical variables affect the quality of water body that in turn influencing algal diversity.

\section{Conclusion and recommendations}

A comprehensive and thorough collection not only of algae but Limnology of river Jindi round the year for a better understanding of the relationship of Algae to water bodies can be conducted. Medicinal studies of these algal species can be conducted for their nutrient value, toxicants, and antimicrobial activities. A limnological profile of various water bodies can be made.

\section{Authors' contributions}

Conceived and designed the experiments: $\mathrm{Z}$ Shah Performed the Fields work and experiments: Z Shah, Analyzed the data: $T$ Khan, K Niaz, M Shuaib Contributed reagents/ materials/ analysis tools: $\mathrm{M}$ 
Shuaib F Hussain, Wrote the paper: Z Shah, SZ Shah, M Shuaib \& F Hussain.

\section{References}

1. Graham \& Wilcox (2000). Algae. Prentice Hall. New York.

2. Shameel M (2001). An Approach to the Classification of Algae in the New Millennium. Pak J Mar Bio 7(182): 233-250.

3. Shameel M (2006). Taxonomic studies on Cymbella (Bacillariophyta) from Punjab and Azad Kashmir. Pak J Bot 38(1): 161-167.

4. Reynolds CS (1980).Phytoplankton assemblages and their periodicity in stratifying lake systems. Holarctic Eciol 3: 141-159.

5. Allott NA (1986). Temperature, Oxygen and Heat budgets of six small Western Irish Lakes. Freshwater Biol 16: 145-154.

6. Ohashi K, Burkart V, Flone S \& Kolb H (2000). Cutting edge: Heat shock protein 60 is a putative endogenous ligand of the toll-like receptor-4 complex. The J of Immu 164(2): 558561.

7. Hall T (1999). Bioedit: A user-friendly biological sequence alignment editor and analysis program for windows 95/98nt. Nucleic acids symposium series.

8. Gaggi C \& Sbrilli G (2009). Hasabelnabyam, bucci $\mathrm{m}$, duccini $\mathrm{m}$, bacci. 1995. Toxicity and hazard ranking of s-triazine herbicides using microtox,two green algal species, and a marine crustacean. Environ Toxicol and Chem 14(6): 1065-1069.

9. Fujimoto N, Sudo R, Sugiura N \& Inamori Y (1997). The nutrient-limited growth of Microcystis aeruginosa and Phormidium tenue AD competition under various $\mathrm{N}: \mathrm{P}$ ratios and temperatures. Limnol Oceanogr 42(2): 250-256.

10. Kotak BG, Lam AKY, Prepas EE \& Hrudey SE (2000). Role of chemical and physical variables in regulating microcystin-LR concentrations in phytoplankton of eutrophic lakes. Can J Fish Aquat Sci 57: 1584-1593.

11. Nixon WF (1992). Quantifying the relationship between nitrogen input and the productivity of marine ecosystems. Proc Adv Marine Tech Conf 5: 57-83.

12. Shuaib M, Ali K, Zeb U, Ahmed S, Ali S, Khan I \& Hussain F (2017). To assess the freshwater algal diversity in relation to water from river Panjkora, district Dir lower, Pakistan. Pure and Appl Biol 6(2): 645-656.

13. Tripathi S, Pathak M \& Tiwari J (2008). A study on organic pollution based on algal distribution in some rural and temple ponds of Balrampur, up India. Environ Conser J 9(3): 61-64.

14. Leghari M \& Ghafar S (2006). Epilithic algal species of Rawal Dam water, Islamabad, Pakistan. Inter $J$ of Phycol and Phycochem 2.

15. Hem J D (1984).Study and interpretation of the Chemical Characteristics of natural water, $3^{\text {rd }}$ edition.Water supply paper 2254, United States Geological Survey Washington, DC.

16. Khan H, Fiaz M, Khan S, Hussain F, Shah SZ, Shah M, Shuaib M, Saeed M, Raza F \& Laghari MK (2017). Taxonomic study of freshwater Green Algae in relation to water quality of Tehsil Landikotal, Khyber Agency, Pakistan. Pure and Appl Biol.

17. Scheffer M (2004). Ecology of shallow lakes .Klumwer Academic Publishers. Dordrecht.

18. Watson SB, McCauley E \& Downing JA (1997). Patterns in phytoplankton taxonomic composition across temperate lakes of differing nutrient status. Limnol Oceanogr 42(3): 487495.

19. Reynolds CS (1984). The ecology of freshwater algae. Cambridge University Press. New York.

20. Prescott GW (1951). Algae of the western great lake area: Exclusive of 
desmids and diatoms, Cranbroo Institute of Science.

21. Tiffany LH \& Britton ME (1952). The Algae of Illionois. Chicago Univ. Press, Chicago Faridi M (1971). The genera of freshwater algae of Pakistan and Kashmir. Biologia 17(2): 123-142.

22. Shah SZ (1985). Ecological Studies on the algae of eroded soil (PhD Thesis). Department of Botany, University of Peshawar.

23. Venkateswarlu V (1991). An ecological study of the algae of the River Moosi, Hyderabad (India) with special reference to water pollution-III: The algalperiodicity. Hydrobiol 34(34): 533-560.

24. Vijaykummar S, Thajuddin $\mathrm{N} \&$ Manoharan C (2005). Role of Cyanobacteria in the treatment of dye industry effluent. Poll Res 24(1): 6974.

25. Hussain F \& Zaman A (2010). Limnological Studies of Some Water Bodies in Peshawar Valley in Relation to Algal Distribution During Summer. PUTAJ 17: 10-15.

26. Imtiaz H, Afridi MS, Naeemulah, Sadiqullah, Hussain Z, Shah M, Shuaib M \& Hussain F (2018). Community assembly and ecology of microalgae of Peshawar, Khyber Pakhtunkhwa, Pakistan. Pak J Weed Sci Res 24(3): 295-300.

27. Salim KM \& Khan MH (1965).The Fresh Water Diatoms of Peshawar Valley. Peshawar University Publishing, Peshawar.

28. Sarim FM, Ahmad I, Ali N \& Zaman A (2010). Cyanophyceae of District Charsadda, Pakistan. Pak J Pl Sci 16(2): 91-98.

29. Nawaz A \& Sarim FM (2004). The Fresh Water Algae of Swat River. PUTAJ 10: 181-183. Zaman A \& Sarim FM (2005). Some Fresh Water Algae of District Charsadda NWFP. PUTAJ 12: 5-10.
30. Anjum G \& Hussain F (1986). Survey for Oscillatoria genus in Quetta Pishin Valley. Pak J Agric Res 7(3): 198-204.

31. Sarim FM \& Ali Q (1986). Effect of Copper Sulphate on the Growth of Cladophora and Glomerata (Chlorophyta). Pak J Bot (2): 359-360.

32. Nishat K, Niaz S \& Sarim FM (1999). Soil Algae of Maize Fields of Mardan District. PUTAJ 6: 77-80.

33. Hussain F \& Zaman A (2010). Limnological Studies of Some Water Bodies in Peshawar Valley in Relation to Algal Distribution during summer. PUTAJ 17: 10-15.

34. Din KSD, Shuaib $M$ \& Hussain $F$ (2017). Documentation of microalgal species from selected regions of Peshawar valley, Khyber Pakhtunkhwa (KPK), Pakistan. Pure and Appl Biol 6(2): 561-575.

35. Leghari MK, Leghari MY \& Leghari SM (2004). Water Chemistry and its Relation with Algae of Rawal Dam, Islamabad and Wah garden, District Attock, Sind Univ. Res J Sci Ser 36(2): 29-48.

36. Leghari SM, Khuhawar MY, Jehangir TM, Leghari \& Abdullah (2005). Limnological Study of Natural Springs at Gharo Creek, District Thatta, Sindh Pakistan. Intern J Phycol Phycochem 1(1): 37- 42.

37. Leland HV, Brown LR \& Mueller DK (2001). Distribution of Algae in the San Joaquin River, California, in Relation to Nutrient Supply, Salinity and other Environmental Factors. Freshwater Biol 46(9): 1139-1167.

38. Sarim FM \& Zaman A (2005). Some freshwater algae of District Charsadda NWFP, Pakistan. PUTAJ 12: 5-10.

39. Leland HV, Brown LR \& Mueller DK (2001). Distribution of Algae in the San Joaquin River, California, in Relation to Nutrient Supply, Salinity and other Environmental Factors. Freshwater Biol 46(9): 1139-1167. 